\title{
The Freshwater System West of the Antarctic Peninsula: Spatial and Temporal Changes
}

\author{
Michael P. Meredith, Hugh J. Venables, And Andrew Clarke \\ British Antarctic Survey, Cambridge, United Kingdom \\ Hugh W. Ducklow AND MatTHew ERICKSON \\ The Ecosystems Center, Marine Biological Laboratory, Woods Hole, Massachusetts \\ MELANIE J. LENG \\ Department of Geology, University of Leicester, Leicester, and \\ NERC Isotope Geosciences Laboratory, \\ British Geological Survey, Keyworth, United Kingdom \\ JAN T. M. LENAERTS AND MichiEL R. VAN DEN BROEKE \\ Institute for Marine and Atmospheric Research, Utrecht, Netherlands
}

(Manuscript received 2 May 2012, in final form 3 September 2012)

\begin{abstract}
Climate change west of the Antarctic Peninsula is the most rapid of anywhere in the Southern Hemisphere, with associated changes in the rates and distributions of freshwater inputs to the ocean. Here, results from the first comprehensive survey of oxygen isotopes in seawater in this region are used to quantify spatial patterns of meteoric water (glacial discharge and precipitation) separately from sea ice melt. High levels of meteoric water are found close to the coast, due to orographic effects on precipitation and strong glacial discharge. Concentrations decrease offshore, driving significant southward geostrophic flows (up to $\sim 30 \mathrm{~cm} \mathrm{~s}^{-1}$ ). These produce high meteoric water concentrations at the southern end of the sampling grid, where collapse of the Wilkins Ice Shelf may also have contributed. Sea ice melt concentrations are lower than meteoric water and patchier because of the mobile nature of the sea ice itself. Nonetheless, net sea ice production in the northern part of the sampling grid is inferred; combined with net sea ice melt in the south, this indicates an overall southward ice motion. The survey is contextualized temporally using a decade-long series of isotope data from a coastal Antarctic Peninsula site. This shows a temporal decline in meteoric water in the upper ocean, contrary to expectations based on increasing precipitation and accelerating deglaciation. This is driven by the increasing occurrence of deeper winter mixed layers and has potential implications for concentrations of trace metals supplied to the euphotic zone by glacial discharge. As the regional freshwater system evolves, the continuing isotope monitoring described here will elucidate the ongoing impacts on climate and the ecosystem.
\end{abstract}

\section{Introduction}

The western Antarctic Peninsula (WAP; Fig. 1) is the most rapidly warming region in the Southern Hemisphere (King 1994). During the second half of the twentieth century, rates of annual-mean atmospheric warming

Corresponding author address: Michael P. Meredith, British Antarctic Survey, High Cross, Madingley Road, Cambridge CB3 OET, United Kingdom.

E-mail:mmm@bas.ac.uk derived from WAP station data were $3.7 \pm 1.6^{\circ} \mathrm{C}$ century ${ }^{-1}$ or $3.4^{\circ} \mathrm{C}$ century ${ }^{-1}$ when weighted by length of record, with the maximum warming concentrated in the austral autumn and winter (Smith et al. 1996; Vaughan et al. 2003). The full causes of this warming have not yet been determined, unlike the summer warming on the eastern side of the Antarctic Peninsula, which has been attributed to an intensification of the southern annular mode (SAM), the dominant mode of extratropical climate variability in the Southern Hemisphere (Marshall et al. 2006). However, there are 


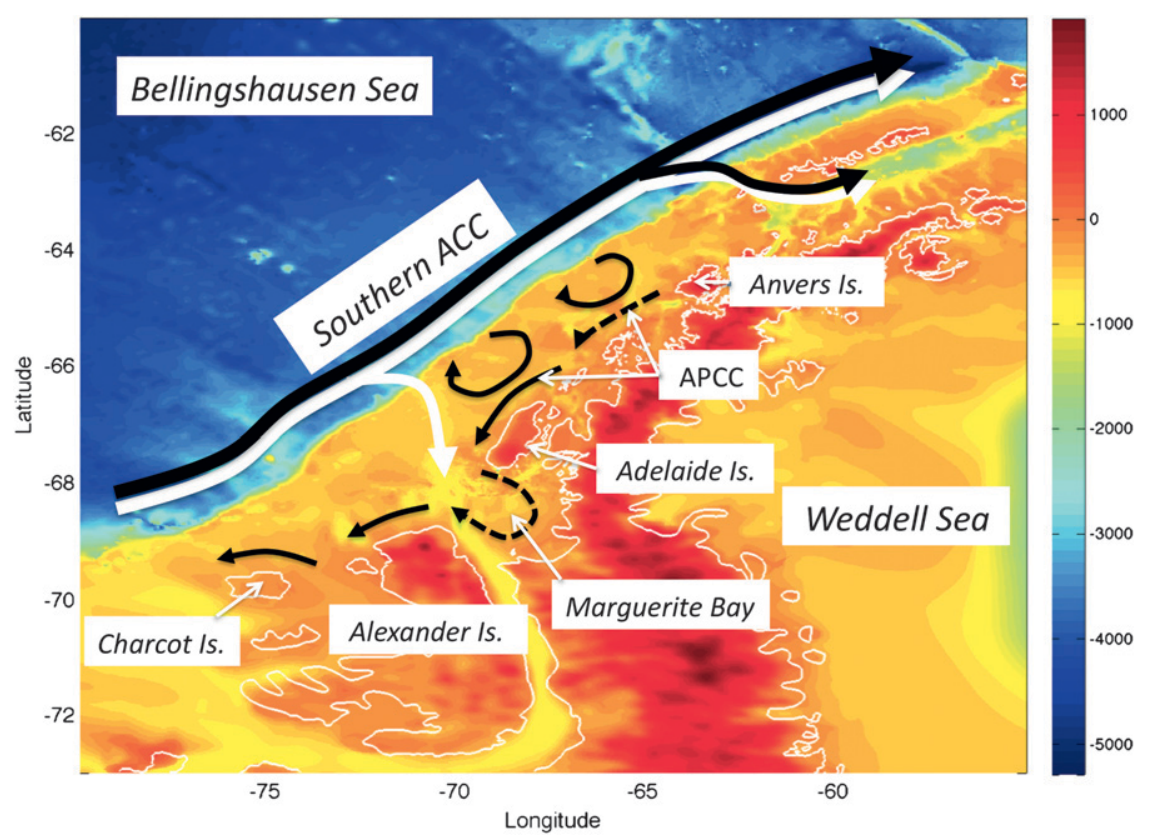

FIG. 1. Bathymetry and topography of the Antarctic Peninsula with selected features marked. Oceanographic flows are marked schematically, with deep currents shown in white and shallow currents shown in black. Flow patterns for which there is strong observational evidence are depicted by solid arrows; flows that are presumed/inferred to exist are depicted by dashed arrows. The APCC is marked, following Moffat et al. (2008).

indications of a link between WAP temperatures and atmospheric circulation, with more cyclonic conditions and increased warm-air advection leading to anomalously warmer winters at the WAP (Turner et al. 1997).

The extent of sea ice adjacent to the WAP is also known to be a significant influence on local atmospheric temperatures, with years of extensive sea ice being markedly colder (King 1994; King and Harangozo 1998; Smith and Stammerjohn 2001; Turner et al. 2005). In this respect, the WAP is unusual compared with other sectors of Antarctica, where katabatic winds and other circulations lead to atmospheric flows with significant southerly components and coastal atmospheric temperatures that depend comparatively little on sea ice extent. In contrast, temperatures at the WAP are especially sensitive to sea ice because the mean winds have a strong westerly component associated with the eastern limb of the Amundsen Sea low (ASL; the dominant feature of atmospheric circulation between the WAP and the Ross Sea); consequently, these winds cross the sea ice before reaching land. The influence of sea ice on coastal temperature at the WAP was elucidated further by Turner et al. (2013), who demonstrated that there has been a progressive tendency toward polynya-like conditions adjacent to Faraday/Vernadsky station (mid-WAP) and who showed that this is instrumental in the reduced frequency of very cold winters there.
Concurrent with the atmospheric warming, there have been some significant changes in the freshwater system along the WAP and in the adjacent Bellingshausen Sea (e.g., Meredith et al. 2010). It has been demonstrated that $80 \%$ of the glaciers at the Antarctic Peninsula were in retreat during the second half of the twentieth century and that rates of retreat have been accelerating (Cook et al. 2005). An increase in the annual duration of melt conditions has also occurred at the WAP and, while the majority of meltwater will percolate down and refreeze in the ice pack, an increase in runoff is expected (Vaughan 2006). Indeed, the Antarctic Peninsula is the one region of Antarctica where temperatures are sufficiently high to enable significant runoff to occur, and meltwater is known to negatively impact the viability of floating ice shelves along the fringes of the Antarctic Peninsula (Scambos et al. 2009). It is estimated that deglaciation at the Antarctic Peninsula is contributing as much to sea level rise as the combined effects of all Alaskan glaciers (Ivins et al. 2011).

Based on shallow ice core data, a trend toward increased precipitation at the WAP in recent decades has been determined (Thomas et al. 2008). A recent regional atmospheric model also showed increased precipitation at the WAP, though it was not possible to demonstrate statistical significance (Lenaerts et al. 2012). From station data, however, there is evidence of rising 
precipitation and more precipitation events and an increasing tendency for the precipitation to fall as rain instead of snow (Kirchgäßner 2011; Turner et al. 1997). This has significant consequences for the erosion of the ice sheet onto which the precipitation falls and also the thermodynamic conditions of the snowpack since additional heat release from rain reduces the ability of the snowpack to refreeze meltwater (note that rain in this region will not have a temperature much above $0^{\circ} \mathrm{C}$; it is the refreezing of rain in the snow and subsequent release of latent heat that is significant).

In the context of freshwater loss from the Antarctic Peninsula, it is worth noting the presence of the Antarctic Peninsula Coastal Current (APCC; Moffat et al. 2008), which lies immediately adjacent to Adelaide Island and Alexander Island (Fig. 1) and is presumed to exist at other coastal locations, albeit in potentially modified form. From a detailed characterization of the APCC, Moffat et al. (2008) argued that it was at least partly driven by freshwater release from land at the WAP and hence might be seasonal in nature. Given the decadal trends in the WAP freshwater system, trends in the intensity of the APCC on similar time scales are a possibility.

A further manifestation of the changing freshwater system at the WAP is the rapid loss of sea ice, perhaps most clearly depicted by the strong trend toward decreased winter sea ice duration (Stammerjohn et al. 2008a). This contrasts with the overall slight increase in circumpolar sea ice, resulting from the compensating effects of the strong positive sea ice trend in the Ross Sea sector (Stammerjohn et al. 2008b; Turner et al. 2009). The shortening of the sea ice season at the WAP is composed of a moderate trend toward earlier retreat in spring coupled with a stronger trend toward later advance in autumn (Stammerjohn et al. 2008a).

The response of the upper ocean adjacent to the WAP to the warming atmosphere and changing freshwater system was investigated by Meredith and King (2005). This study demonstrated that the ocean had undergone a surface-intensified warming in excess of $1{ }^{\circ} \mathrm{C}$ during the second half of the twentieth century, with warming rates decreasing to near-zero at around 100-m depth. Coupled to this was a summertime salinification of the surface ocean caused by the changing air-sea-ice interactions. Crucially, it was demonstrated that these ocean trends are more than just responses to the atmospheric and cryospheric changes but act as positive feedbacks to sustain and enhance the climatic change at the WAP.

There are other oceanic influences that can impact on climatic change at the WAP, most notably the intrusion onto the shelf of warm Circumpolar Deep Water (CDW) from the midlayers of the Antarctic Circumpolar Current (ACC) (Fig. 1; Martinson 2011a,b). Unlike most
Antarctic shelf regions, which are separated from the ACC by expansive subpolar gyres, the southern edge of the ACC lies immediately adjacent to the shelf slope at the WAP. CDW from the ACC penetrates the WAP shelf most easily in regions where the shelf is dissected by glacially scoured canyons such as the Marguerite Trough (Fig. 1) (Martinson et al. 2008; Moffat et al. 2009). Once on the shelf, the CDW is modified by interaction with the overlying water masses, and the associated vertical transfer of heat, salt, and nutrients is significant for the properties of the upper ocean of the WAP shelf (Hofmann et al. 1996; Klinck 1998; Martinson et al. 2008).

The water that overlies CDW at the WAP is Antarctic Surface Water, which comprises a relatively deep mixed layer in winter but becomes stratified in summer because of heating and freshening from insolation and ice melt respectively. The remnant of the winter mixed layer that persists into summer as a temperature minimum at $50-150-\mathrm{m}$ depth is termed Winter Water (WW). It is believed that shallow regions near the coast may be especially important for vertical mixing between these water masses, driven by processes such as coastal upwelling and the influence of internal tides (Wallace et al. 2008).

$\mathrm{CDW}$ has the potential to induce changes in the WAP climate and ecosystem both through its well-documented decadal warming (e.g., Gille 2008) and also through an acceleration of its on-shelf flow linked to stronger winds and the intensification of the SAM (Martinson et al. 2008; Thoma et al. 2008). The role of eddy processes in facilitating the on-shelf and along-shelf flow of CDW was highlighted recently (Martinson 2011b; Moffat et al. 2009), and it was shown that increases in ice shelf loss are being caused by greater basal melting driven by a warmer ocean, at the WAP and elsewhere around Antarctica (Pritchard et al. 2012).

Each of these changes in the WAP freshwater system has the potential to exert influence on the regional ecosystem, and many such impacts are now being observed (Ducklow et al. 2012). A significant factor in this is the nature of the equation of state for seawater at low temperature, which prescribes that temperature is virtually a passive tracer in the polar oceans and that the distribution of density is determined almost entirely by that of salinity. Consequently, a thin layer of ice melt upon the ocean surface will act to enhance stratification significantly and greatly stabilize the water column, thereby creating an environment more favorable for phytoplankton blooms (Dierssen et al. 2002; Mitchell and Holm-Hansen 1991). In this context, it is important to note that phytoplankton biomass at the WAP has shown an overall decrease since the late 1970s (MontesHugo et al. 2009), with this change comprising separate trends in the northern and southern regions. In the 
north, increased cloudiness and wind-induced mixing drove a decrease in biomass, whereas in the south the decreasing sea ice and clouds and increasing water column stratification led to an opposite trend. These trends have potentially significant consequences for higher trophic levels also, including Antarctic krill and penguin populations (Montes-Hugo et al. 2009).

The impact of changes in sea ice and upper-ocean stratification on WAP productivity was also explored recently by Venables et al. (2013), who used a long time series of year-round oceanographic measurements from northern Marguerite Bay (adjacent to Adelaide Island; Fig. 1) to demonstrate that years with low winter sea ice concentration are characterized by reduced upper-ocean stratification that persists into the following spring, with impacts on the magnitude of the phytoplankton bloom. The increasing frequency of such years was linked to a tendency toward more persistent northerly winds; these drive the sea ice southward, maintaining polynya-like conditions during winter and hence enable ice production to be maintained for longer periods.

A further significant influence of the freshwater system on the WAP marine ecosystem derives from the potential role of glaciers in supplying trace metals such as iron to the ocean (Dierssen et al. 2002; Edwards and Sedwick 2001; Raiswell 2011). Scouring of the underlying rock and sediment, as well as accumulation from atmospheric deposition, can lead to glacial ice being a significant source of such micronutrients (Annett et al. 2013), the low levels of which limit productivity in large regions of the open Southern Ocean (for a review, see Boyd and Ellwood 2010). It has been suggested that an increase in freshwater input to the ocean from glaciers could result in a shift in phytoplankton assemblage composition and an increase in biomass in the waters influenced (Dierssen et al. 2002).

Previously, we have investigated temporal changes in freshwater inputs to the ocean adjacent to the WAP using the ratio of stable isotopes of oxygen in seawater $\left(\delta^{18} \mathrm{O}\right.$, the standardized ratio of $\mathrm{H}_{2}^{18} \mathrm{O}$ to $\mathrm{H}_{2}^{16} \mathrm{O}$ ). Such data are extremely useful when collected alongside measurements of salinity, since the combination of tracers enables sea ice melt input to be quantified separately from meteoric water input (where meteoric water is here the combination of precipitation and glacial ice melt; Craig and Gordon 1965). These previous studies used data from a nearcoastal site in northern Marguerite Bay (Fig. 1) to investigate the variability in freshwater inputs on seasonal (Meredith et al. 2008) and interannual (Meredith et al. 2010) time scales. It was found that the seasonality in meteoric water was similar to that in sea ice melt (around $1 \%-2 \%$ of the total volume of the water) and that meteoric water was the dominant freshwater source overall, contributing up to $5 \%$ during summer (Meredith et al. 2008). It was further noted that strong interannual changes were present in the time series, often linked to climatic variability associated with the SAM and the El NiñoSouthern Oscillation phenomenon (Meredith et al. 2010).

Such insights highlight the need for more information on the spatial patterns and impacts of freshwater inputs to the broader WAP ocean. Here, we present the first extensive survey of $\delta^{18} \mathrm{O}$ in seawater from the ocean adjacent to the WAP. We use this dataset to generate results pertaining to the spatial distribution of freshwater inputs, the relative importance of different freshwater sources, and their effects on ocean characteristics and flows. We set these results in the context of longterm temporal changes in freshwater inputs, as reflected in data from our monitoring site in Marguerite Bay, to gain insight into how the patterns have evolved.

\section{Methods}

\section{a. Sample collection and analysis}

Two primary $\delta^{18} \mathrm{O}$ datasets are used here. The first was obtained during the Palmer Long-Term Ecological Research (Pal-LTER; http://pal.lternet.edu/) January 2011 cruise along the WAP aboard Antarctic Research and Supply Vessel (ARSV) Laurence M. Gould. During this cruise, samples were drawn routinely for isotope analysis from the underway water supply (5-m depth), and also from Niskin bottles closed at various depths during concurrent profiling with a SeaBird 911plus conductivity-temperature-depth (CTD) instrument. The spatial pattern of sampling and data coverage is indicated by the distributions of salinity and $\delta^{18} \mathrm{O}$ shown in Fig. 2. Accuracy of the Pal-LTER salinity data is around 0.002 .

The second dataset used is from the Rothera Oceanographic and Biological Time Series (RaTS) program (http://www.antarctica.ac.uk/rats) of year-round, sustained observations in northern Marguerite Bay, adjacent to Adelaide Island (Fig. 1). RaTS measurements are made quasi weekly, including profiling with a SeaBird 19plus CTD using a hand-cranked winch. This profiling is conducted from a rigid inflatable boat during the ice-free months and through a hole cut in the sea ice when ice cover prevents safe access to the sampling site by boat. In addition to CTD profiling, samples are drawn from a Niskin deployed to $15-\mathrm{m}$ depth. These are analyzed for a range of physical, biogeochemical, and biological parameters, including $\delta^{18} \mathrm{O}$. RaTS CTD salinities are calibrated against independent bottle samples and by annual joint calibrations with the SeaBird 911plus onboard the ARSV Laurence $M$. Gould. Calibrated salinity used here is accurate to better than 0.005 . 
(a)

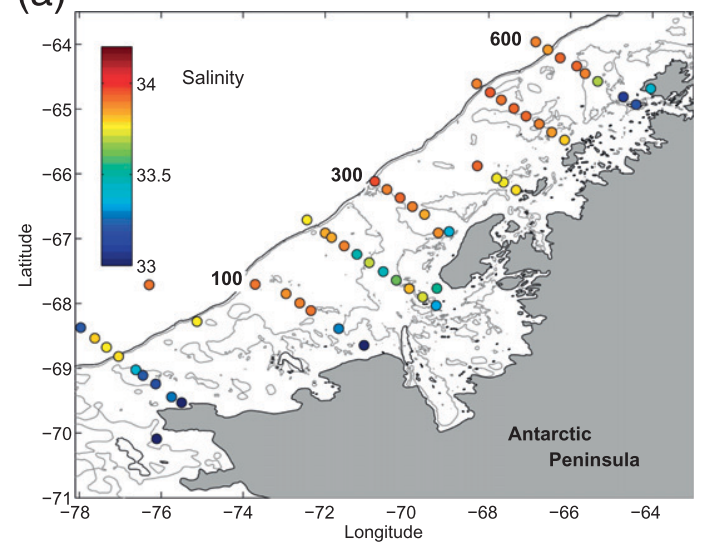

(b)

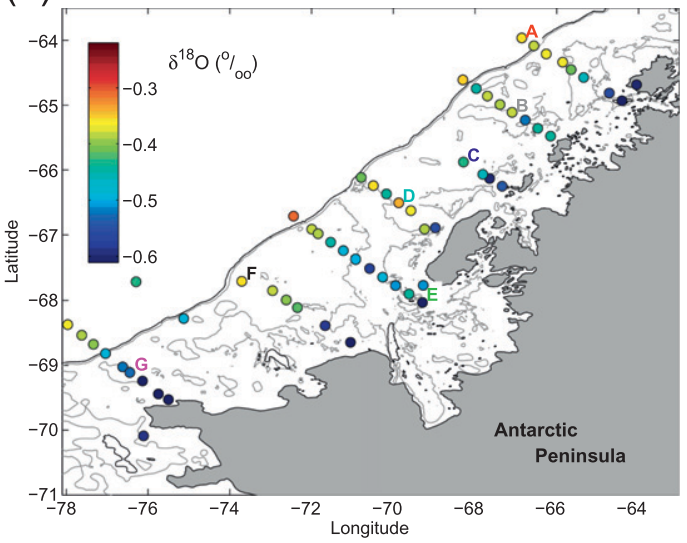

(c)

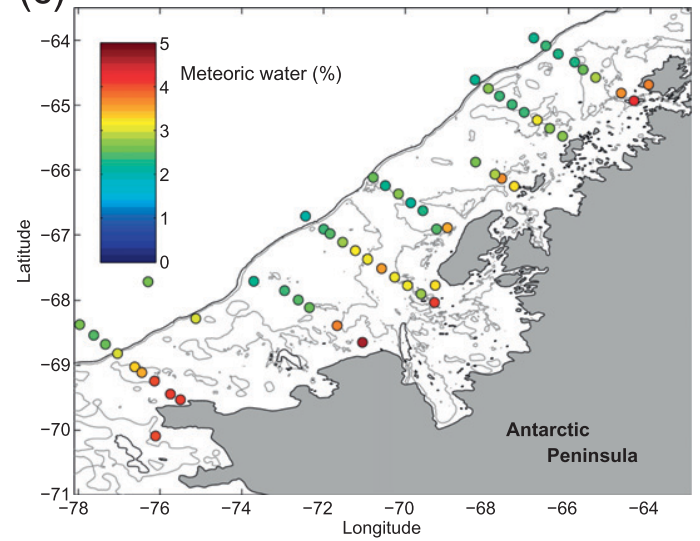

(d)

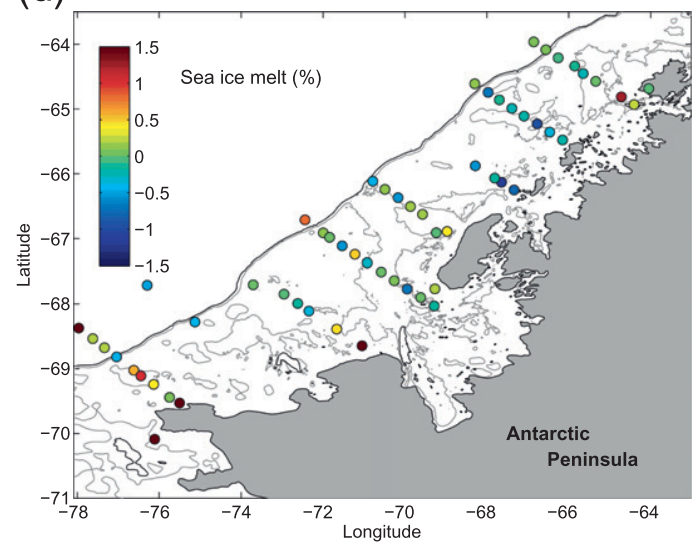

FIG. 2. (a) Salinity at the locations from which near-surface samples were drawn for $\delta^{18} \mathrm{O}$ analyses during the L. M. Gould cruise in January 2011. Note locations of comparatively fresh waters close to the WAP coast, in particular near Anvers Island, Adelaide Island, Alexander Island, and Charcot Island (marked in Fig. 1). The locations of sections 600, 300, and 100 (plotted in Fig. 4) are marked. The 1000- and 500-m isobaths are shown (black and gray lines, respectively). (b) As in (a), but for $\delta^{18} \mathrm{O}$. Note that the waters closest to the coast are the lightest isotopically of those surveyed. Selected stations marked with letters are those displayed as vertical profiles in Fig. 3. (c) As in (a), but for the percentage of water from a meteoric freshwater source, derived from salinity and $\delta^{18} \mathrm{O}$ using the mass balance shown in Eq. (1). Note the high values $(\sim 5 \%)$ in near-surface waters close to areas of the WAP coast, decreasing to around $2 \%$ at the shelf break. (d) As in (c), but for the percentage of water sampled derived from sea ice melt. Note that values can be negative and positive, reflecting both net sea ice formation and melt in the different waters sampled. Values are generally lower than for freshwater from meteoric sources and more scattered spatially.

Pal-LTER samples were drawn into 50-ml glass vials, which were sealed with stoppers and aluminum crimps to prevent evaporation. RaTS samples were drawn into 150$\mathrm{ml}$ medical flat bottles, with rubber inserts in the caps; these were sealed further with Parafilm. The $\delta^{18} \mathrm{O}$ samples were then transported to the United Kingdom via dark cool stow $\left(4^{\circ} \mathrm{C}\right)$, where they were analyzed at the Natural Environment Research Council Isotope Geosciences Laboratory (NIGL) at the British Geological Survey. The method of analysis is the equilibrium method for oxygen (Epstein and Mayeda 1953), with samples run on a VG Isoprep 18 and SIRA 10 mass spectrometer. Random duplicates were analyzed to establish precision, with an average better than $\pm 0.02 \%$ achieved.

\section{b. Determination of freshwater concentrations}

The oceanic distribution of $\delta^{18} \mathrm{O}$ is determined largely by the same processes that control salinity. Surface $\delta^{18} \mathrm{O}$ reflects the magnitude and spatial distribution of freshwater inputs, and it is a conservative tracer in the ocean interior. The great benefit of $\delta^{18} \mathrm{O}$ is obtained from the circumstances under which it exhibits behavior different to that of salinity. One such circumstance derives from the salinity and $\delta^{18} \mathrm{O}$ values in precipitation, with salinity being constant with latitude (typically zero), while in general $\delta^{18} \mathrm{O}$ in precipitation becomes progressively isotopically lighter toward the poles because of rainout and temperature differences. This results in glacial ice 
(which derives from high-latitude precipitation) being very isotopically light, enabling $\delta^{18} \mathrm{O}$ to be a useful tracer of glacial discharge to the ocean (e.g., Schlosser et al. 1990; Weiss et al. 1979). Another difference occurs in regions influenced by sea ice, which greatly affects salinity during its formation/melt cycle but has only minimal impact on $\delta^{18} \mathrm{O}$. This decoupling of the two tracers allows them to be used in tandem to quantitatively separate freshwater inputs from sea ice melt and those from meteoric sources (precipitation plus glacial discharge). For this, a simple three-endmember mass balance can be used, which was developed by Ostlund and Hut (1984) for the Arctic and implemented at the WAP by Meredith et al. $(2008,2010)$. At the WAP, this mass balance takes the form

$$
\left[\begin{array}{l}
f_{\text {sim }}+f_{\text {met }}+f_{\text {cdw }}=1 \\
f_{\text {sim }} \cdot f_{\text {sim }}+S_{\text {met }} \cdot f_{\text {met }}+S_{\mathrm{cdw}} \cdot f_{\mathrm{cdw}}=S \\
\delta_{\text {sim }} \cdot f_{\mathrm{sim}}+\delta_{\text {met }} \cdot f_{\text {met }}+\delta_{\mathrm{cdw}} \cdot f_{\mathrm{cdw}}=\delta
\end{array}\right],
$$

where $f_{\text {sim }}, f_{\text {met }}$, and $f_{\text {cdw }}$ are the fractions of sea ice melt, meteoric water, and CDW, respectively, that we seek to determine; $S_{\mathrm{sim}}, S_{\mathrm{met}}$, and $S_{\mathrm{cdw}}$ are the respective salinities of the pure components of sea ice melt, meteoric water, and $\mathrm{CDW}$; and $\delta_{\text {sim }}, \delta_{\text {met }}$, and $\delta_{\text {cdw }}$ are their corresponding $\delta^{18} \mathrm{O}$ values. The quantities $S$ and $\delta$ are the measured values of salinity and $\delta^{18} \mathrm{O}$ in each water sample for which the sea ice and meteoric freshwater contributions are being derived.

Solving this system of equations is straightforward, since there are as many equations as unknowns that we are solving for. Formally, our system is exactly determined, and our approach differs from different inverse techniques that are often used for underdetermined systems, and optimal multiparameter (OMP) analyses that are possible for overdetermined systems. [Note that OMP is not appropriate in this case, since it requires an equal or greater number of parameters to be measured as contributing water types that are being solved for (Tomczak and Large 1989)].

Implementing the mass balance given in Eq. (1) requires knowledge of the endmember values for the three different constituent components of the system, namely pure meteoric water, sea ice melt and CDW. Here, we assign values of 34.73 and $0.1 \%$ for the salinity and $\delta^{18} \mathrm{O}$ of the CDW endmember, respectively. Sea ice melt is assigned corresponding values of 7 and $+2.1 \%$, and meteoric water is assigned values of 0 and $-16 \%$. Meredith et al. $(2008,2010)$ contain full discussions on the derivation of endmember values at the WAP and the relevant uncertainties. Briefly, however, the mean CDW endmember is well constrained by measurements (Meredith et al. 2008, 2010, and data presented here), with uncertainties less than 0.05 in both salinity and $\delta^{18} \mathrm{O}$. The mean sea ice melt endmembers are also well constrained, with sea ice salinity at the WAP being well measured and sea ice $\delta^{18} \mathrm{O}$ being related to surface seawater $\delta^{18} \mathrm{O}$ by a known fractionation factor (Lehmann and Siegenthaler 1991; Meredith et al. 2008). The uncertainty in the mean salinity of the meteoric water is assumed to be negligibly small compared with other uncertainties. The largest uncertainty in the derivation of the freshwater fractions derives from the mean meteoric water $\delta^{18} \mathrm{O}$ endmember, since it is a combination of local precipitation and glacial melt, which both can vary spatially and temporally. Consequently, large uncertainties are ascribed to this mean endmember $( \pm 5 \%)$, based on data that include ice core measurements (e.g., Morgan 1982; Potter and Paren 1985; Thomas et al. 2009; etc.) and data from the International Atomic Energy Agency (IAEA) Global Network of Isotopes in Precipitation (GNIP). Possible temporal variability in the mean endmember values is contained within the ascribed uncertainties, as assessed by our own time series data, isotopic values in highresolution shallow ice core data from the Antarctic Peninsula (Abram et al. 2011; Mulvaney et al. 1992; Thomas et al. 2009; Thompson et al. 1994), and so on. For example, seasonal and interannual variations in $\delta^{18} \mathrm{O}$ in precipitation (as reflected in high-resolution shallow ice cores at the Antarctic Peninsula) are typically on the order of $5 \%$ or smaller (Thomas et al. 2009; Thompson et al. 1994; etc.), much less than the total range in the uncertainty of the mean meteoric water endmember. Note further that the endmember value represents mean input from glacial melt and precipitation to the ocean across a geographical area and hence will be significantly less variable than the precipitation itself recorded at a point location.

Uncertainties in the endmembers are used in sensitivity studies to obtain overall uncertainties in the derived freshwater fractions, as per Meredith et al. (2008, 2010). Uncertainty is better than $1 \%$ for point values, reducing as averages of multiple samples are considered, and is carried forward into the derivation of column inventories of freshwater that are compared with surface mass balance (SMB) predictions below.

Note that the endmember values used here differ slightly from those used previously, since earlier studies focused specifically on freshwater inputs in the small region of northern Marguerite Bay, and hence the endmember values were set to be appropriate for that specific location. Here we are concerned with the broader WAP shelf; hence, we use endmember values that are more appropriate to this larger region. Consideration was given to the potentially broader range of input values for $\delta^{18} \mathrm{O}$ 
over this larger area of the WAP shelf (see, e.g., Morgan 1982), and it should be noted that on a regional scale the $\delta^{18} \mathrm{O}$ value of precipitation and glacial input to the ocean is not just a simple relationship with latitude. The difference in derived freshwater fractions using the new endmember values is, however, minimal (less than $0.5 \%$ for meteoric water and typically $0.2 \%$ for sea ice melt).

Where vertical profiles are available, integration of the fractions of meteoric water and sea ice melt with depth yields column inventories of freshwater content. Uncertainties in these are discussed in detail in Meredith et al. $(2008,2010)$; they are maximum around $1 \mathrm{~m}$ for a single station, decreasing as vertical resolution of sampling is increased. Where groups of profiles are available, a mean inventory can be derived with a standard error that decreases as the number of profiles available is increased.

A modified version of the three-endmember mass balance is also used here, so as to determine the freshwater inputs to the ocean since the time that restratification of the ocean commenced after winter. For this, we replace $\mathrm{CDW}$ in the system of equations with properties of the winter mixed layer (WML). Accordingly, the mass balance becomes

$$
\left[\begin{array}{l}
f_{\mathrm{sim}}+f_{\mathrm{met}}+f_{\mathrm{wml}}=1 \\
S_{\mathrm{sim}} \cdot f_{\mathrm{sim}}+S_{\mathrm{met}} \cdot f_{\mathrm{met}}+S_{\mathrm{cdw}} \cdot f_{\mathrm{wml}}=S \\
\delta_{\mathrm{sim}} \cdot f_{\mathrm{sim}}+\delta_{\mathrm{met}} \cdot f_{\mathrm{met}}+\delta_{\mathrm{cdw}} \cdot f_{\mathrm{wml}}=\delta
\end{array}\right],
$$

where $S_{\mathrm{wml}}$ and $\delta_{\mathrm{wml}}$ are assigned values of 33.92 and $-0.38 \%$, respectively, based on year-round sampling at the RaTS site and the properties of the WW layer across the Pal-LTER grid (Martinson et al. 2008). (Being the remnant of the WML, WW preserves some of the properties that the mixed layer had the previous winter and, while the temperature minimum core of the $\mathrm{WW}$ is eroded through spring and summer by vertical mixing, the salinity is less affected by this mixing since it is not a property extremum.)

\section{c. SMB determination}

For quantitative information on the spatial inputs of freshwater to the ocean and over land at the WAP, we use SMB determinations from a high-resolution $(27 \mathrm{~km})$ regional atmospheric climate model of the Antarctic region (RACMO2.1/ANT; Lenaerts et al. 2012). This was run for the period 1979-2010 and forced by European Centre for Medium-Range Weather Forecasts (ECMWF) Interim Reanalysis (ERA-Interim) fields at the lateral boundaries. Reanalysis depictions of highlatitude precipitation were noted to be problematic by Nicolas and Bromwich (2011); however, ERA-Interim was highlighted as the most reliable among these products. Over land, SMB in RACMO2.1/ANT is determined as

$$
\mathrm{SMB}=\int\left(P-\mathrm{SU}_{s}-\mathrm{RU}-\mathrm{ER}_{\mathrm{ds}}-\mathrm{SU}_{\mathrm{ds}}\right) d t,
$$

where $P$ is precipitation, $\mathrm{SU}_{s}$ is surface sublimation, $\mathrm{RU}$ is meltwater runoff, $\mathrm{ER}_{\mathrm{ds}}$ is erosion by drifting snow, and $\mathrm{SU}_{\mathrm{ds}}$ is sublimation of drifting snow. Of these terms, precipitation dominates at the WAP, and the remaining terms are of second-order significance. Over the ocean and sea ice, SMB in RACMO equals total precipitation. Lenaerts et al. (2012) provide assessments of uncertainty for each of the SMB terms. They also compare the output fields of this model with observations and demonstrate that it provides a realistic assessment of the SMB of the Antarctic. The SMB values are used in various contexts here, including a derivation of the glacial discharge at the western coast of the WAP, whereby we quantify total SMB over the region of interest at the WAP and equate this gain of freshwater over land with loss to the ocean. This involves the reasonable assumption that the WAP glacial field is in near-steady state over the time scale of interest (a small number of years).

\section{Results}

\section{a. Spatial patterns of freshwater}

The overall spatial distribution of freshwater in the ocean west of the Antarctic Peninsula in January 2011 is apparent from the salinity field (Fig. 2a). Salinities are lower in the upper ocean than in the underlying CDW, reflecting the inputs of freshwater at the surface; this results in a statically stable water column at low temperatures (cf. Fig. 2a; cf. Fig. 3a). The surface layers are freshest close to the coast almost everywhere, with a few locations showing markedly low salinities. Specifically, the regions adjacent to Anvers Island and south of Adelaide Island have salinities lower than 33.5, the region adjacent to the northwest tip of Alexander Island has salinity lower than 33 , and the area close to Charcot Island has salinity around 32 .

Some preliminary insight into the sources of freshwater responsible for these salinities can be obtained by comparison with the spatial distribution of $\delta^{18} \mathrm{O}$ (Fig. 2b). The surface waters are isotopically lighter than the underlying CDW (typically around $-0.4 \%$; Fig. $2 b$; cf. Fig. $3 \mathrm{~b}$ ), indicating significant meteoric water input to the surface layers everywhere west of the Antarctic Peninsula: sea ice processes alone could not reconcile these two tracer distributions. The surface layers close to the WAP coast are isotopically lighter than those nearer the shelf break, typically by around $0.2 \%-0.3 \%$, indicating strong 

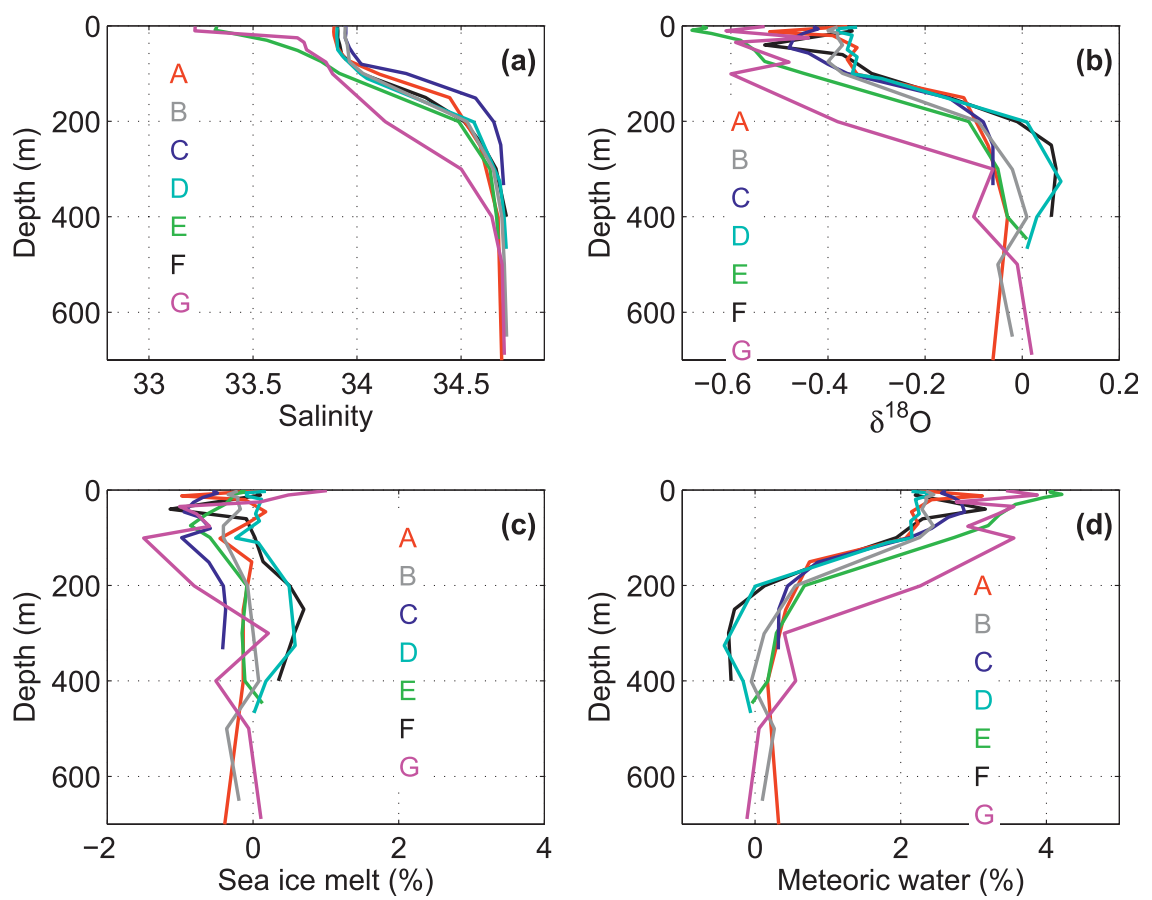

FIG. 3. Selected profiles of (a) salinity, (b) $\delta^{18} \mathrm{O}$, (c) sea ice melt, and (d) meteoric water for selected stations marked in Fig. 2b. Values for (c),(d) were derived using Eq. (1). Stations are color coded and lettered according to location (Fig. 2b).

regional input of meteoric water at the coast and innershelf region. The same areas of markedly low salinity seen in Fig. 2a are also characterized by isotopically light (lower $\delta^{18} \mathrm{O}$ ) water, indicating that glacial discharge and/or precipitation must contribute strongly to the fresher waters observed.

To assess the inputs more quantitatively, the mass balance shown in Eq. (1) is applied to these fields. From this, we find that surface waters west of the Antarctic Peninsula have around 2\% meteoric water in the outer shelf region, rising to $3 \%-5 \%$ close to the coast (Fig. $2 \mathrm{c}$ ). The corresponding distribution of sea ice melt (Fig. 2d) shows lower values in general, ranging from -1 to $+1 \%$ over most of the WAP shelf, though with some isolated higher values in excess of $2 \%$. Note that negative values for sea ice melt denote waters from which there had been net sea ice formation prior to being sampled: that is, a salinification of the water through brine rejection rather than a freshening through melt. The system of equations used to derive sea ice melt permits quantification of this sea ice formation on equal terms with melt and hence allows for quantification of both phases of the annual sea ice cycle.

The cross-shelf gradients in freshwater composition can be seen clearly in the horizontal transects that run from the shelf edge to the coast. For the northernmost line of the cruise (the 600 line marked in Fig. 2a), the peak meteoric water prevalence does not coincide spatially with the freshest water, which is located a few stations offshore because of an isolated patch of elevated sea ice melt (Fig. 4a). At this station, sea ice melt is around $1 \%$, compared with close to $0 \%$ for the rest of the transect. Nonetheless, a general pattern on this section of elevated meteoric water prevalence (up to around $4 \%$ ) closer to the coast is clear. The corresponding horizontal transect for the line located adjacent to Adelaide Island (the 300 line marked in Fig. 2a) shows an even clearer example of this eastern intensification (Fig. 4b). On this line, sea ice melt makes minimal contribution to the spatial distribution of salinity, and the fresher water immediately next to the coast is due entirely to meteoric water input, again with peak values up to $4 \%$. This is not the case everywhere, however, as evidenced by the line that was occupied across the shelf adjacent to northern Alexander Island (the 100 line marked in Fig. 2a). This showed values for meteoric water and sea ice melt that were elevated by comparable amounts in the near-coast region relative to the outer WAP shelf area (over $4 \%$ compared with $2 \%$ for meteoric water, and around $2 \%$ compared with $0 \%$ for sea ice melt; Fig. 4c). While meteoric water is the dominant freshwater input, here and elsewhere on the WAP shelf, the horizontal gradient in surface salinity on this transect derives from approximately 

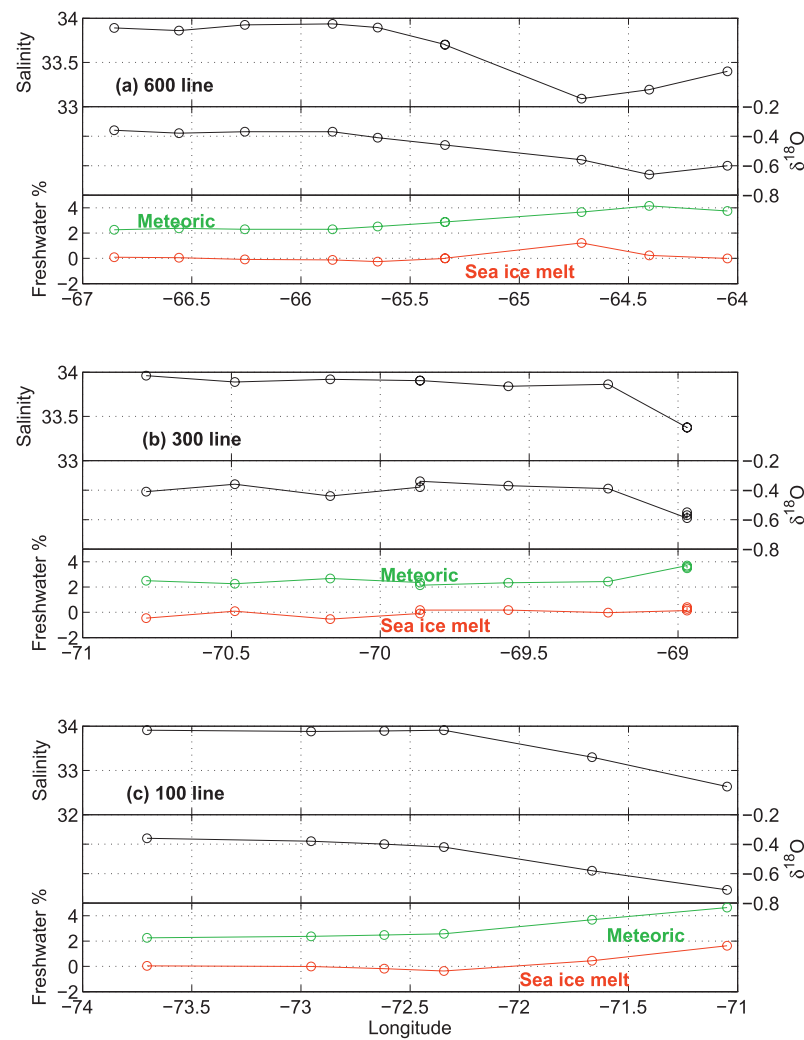

FIG. 4. Horizontal near-surface transects of salinity, $\delta^{18} \mathrm{O}$, and freshwater concentrations along (a) the northernmost line on the summer 2011 survey (line marked 600 in Fig. 2a). Note that the water is fresher closer to the coast, but the very freshest water is not found at the coast itself, due to a significant input of sea ice melt offshore. (b) As in (a), but for the 300 line. Note the water with high meteoric freshwater content immediately adjacent to the coast. (c) As in (a), but for the 100 line. Note the comparable horizontal gradients in both meteoric water and sea ice melt.

equal contributions from both sea ice melt and meteoric water.

The overall spatial pattern of sea ice melt (Fig. 2d) shows relatively more scatter than that of meteoric water, consistent with the more mobile nature of the sea ice itself. There is, however, some spatial structure in the pattern of sea ice melt, which is best observed in $\delta^{18} \mathrm{O}-$ salinity space. Figure 5 shows the near-surface data from the cruise displayed this way, and it is apparent that the influence of sea ice formation (salinification due to freezing) is most significant toward the northern end of the cruise grid, while the influence of sea ice melt (freshening) predominates toward the southern end. It is unsurprising that the magnitude of the sea ice melt signal seems greater than the freeze signal in Fig. 5: mixed layers are shallower in summer and hence the anomaly due to melt is concentrated more in the near-surface layers, whereas the anomaly due to freezing is distributed over the much deeper winter mixed layer.

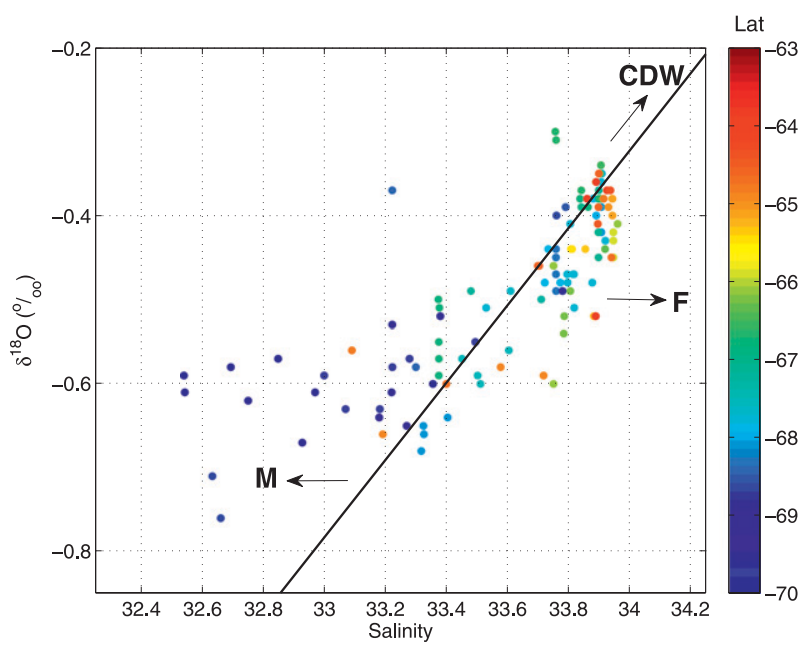

FIG. 5. Near-surface samples from the 2011 Pal-LTER cruise, displayed in $\delta^{18} \mathrm{O}-$ salinity space and color coded by latitude. The diagonal line denotes the meteoric water-CDW mixing line: if these were the only two sources, all data points would lie on this line. Deviations from this line are due to freezing $(\mathrm{F})$ and melting (M) of sea ice and the associated salinification or freshening of the water. Note that freezing generally happens at lower latitudes than melting.

Understanding of the spatial pattern of meteoric water is enhanced by consideration of the distribution of SMB in the Antarctic Peninsula region (Fig. 6; note that SMB equals precipitation in RACMO except over land). Over much of the open ocean, SMB values are

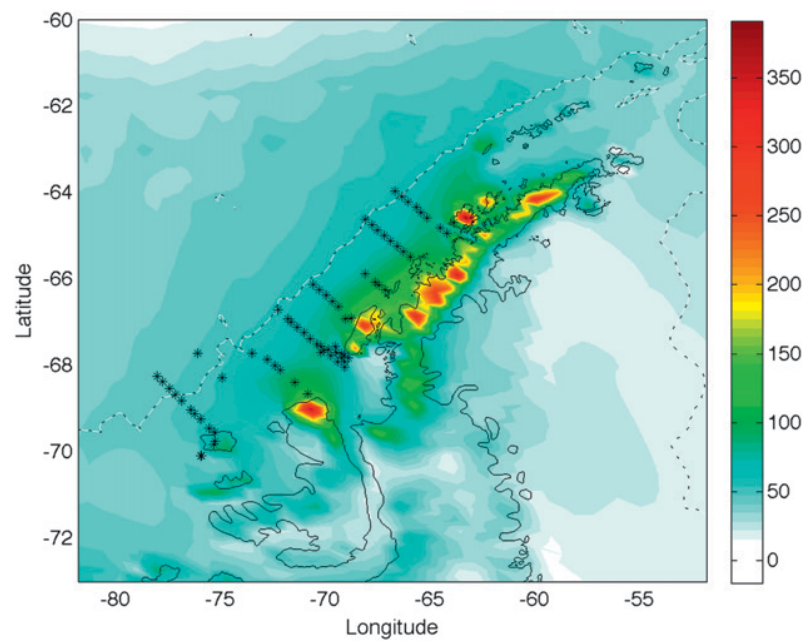

FIG. 6. Mean SMB from the RACMO model, in millimeters per month (note that, over ocean and sea ice, RACMO SMB equals total precipitation). Locations of samples drawn for $\delta^{18} \mathrm{O}$ analysis are marked (asterisks). Note the high values over land on the western side of the Antarctic Peninsula, due to orographic effects. Note also the relatively high values over the ocean adjacent to the WAP, due to uplift upstream of the barrier. 
comparatively low, with a mean around $50 \mathrm{~mm}$ month $^{-1}$. Conversely, SMB is very high over land on the western side of the Antarctic Peninsula, with peak values exceeding $300 \mathrm{~mm} \mathrm{month}^{-1}$. This distribution of high SMB is spatially variable because of the mountainous topography of the Antarctic Peninsula, but there are high values from around $64^{\circ} \mathrm{S}$ down to the latitude of Adelaide Island and also at the northern tip of Alexander Island. Over the ocean on the inner part of the WAP shelf, precipitation is higher than over the outer shelf and the open ocean, with typical values around 100$150 \mathrm{~mm}$ month $^{-1}$ caused by uplift of atmospheric surfaces upstream of the barrier. The Pal-LTER sampling grid is well placed to capture much of this freshwater injected to the ocean (asterisks in Fig. 6 denote $\delta^{18} \mathrm{O}$ samplings).

\section{b. Flux and budget calculations}

An estimate of meteoric water input to the ocean west of the Antarctic Peninsula can be made using $\delta^{18} \mathrm{O}$ mass balance calculations alone. For this, the average salinity and $\delta^{18} \mathrm{O}$ properties of the WW across the Pal-LTER grid were derived and taken to be representative of the properties of the deep WML. Year-round sampling from RaTS confirms this to be a reasonable assumption. The three-endmember mass balance given in Eq. (2) was then used to derive the extra meteoric water injected to the ocean since the time that seasonal restratification of the mixed layer commenced in spring. Unsurprisingly, the spatial pattern of meteoric water distribution relative to the WML shows marked similarities with the distribution of meteoric water overall (Fig. 7; cf. Fig. 2c), since the former is a subset of the latter. When integrated down to the average depth of the WW in the 2011 Pal-LTER box, the mean extra meteoric water added to the water column since restratification commenced was found to be approximately $0.5 \mathrm{~m}$, with a standard error around $0.05 \mathrm{~m}$.

RaTS CTD data indicate that the WML began to restratify in early October 2010, coincident with a marked retreat of the sea ice at the WAP at that time, as determined from satellite microwave remote sensing imagery (not shown). This gives a time scale of approximately 3 months during which the extra meteoric freshwater accumulated in the ocean prior to being sampled on the January 2011 Pal-LTER cruise.

Mean RACMO2.1/ANT values over the Pal-LTER grid region give a corresponding rate of $75 \mathrm{~mm} \mathrm{month}^{-1}$ for direct net input of freshwater as precipitation to the ocean or approximately $225 \mathrm{~mm}$ for the 3 -month period prior to the January 2011 Pal-LTER cruise. We note that the mean rate of $75 \mathrm{~mm}$ month $^{-1}$ averages variability on a range of time scales (including seasonal) and that the

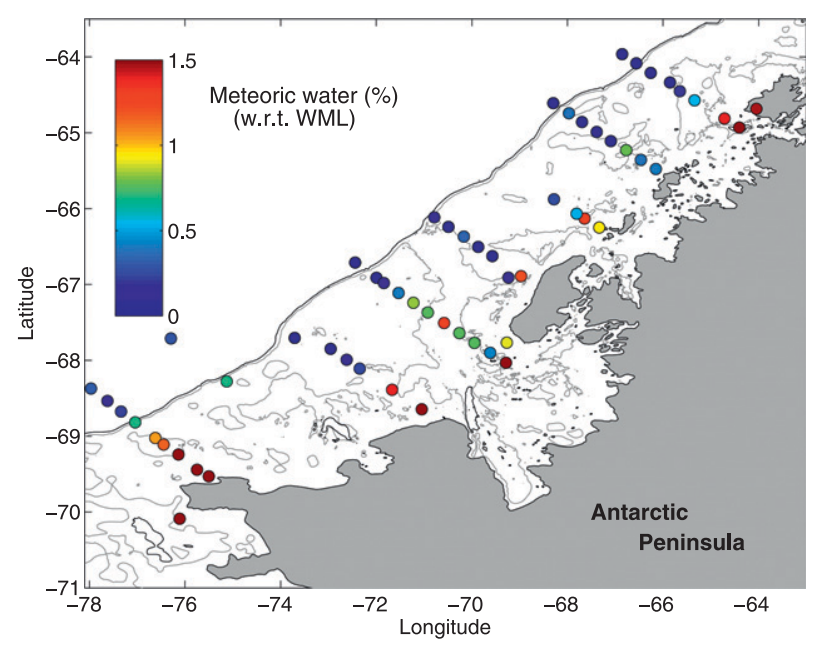

FIG. 7. Percentage of meteoric freshwater in the waters sampled, derived from salinity and $\delta^{18} \mathrm{O}$ using the mass balance shown in Eq. (2). Values are here relative to the properties of the winter mixed layer and hence represent the meteoric water added subsequent to the onset of restratification of the upper ocean in spring. The highest values are immediately adjacent to Anvers Island, Adelaide Island, Alexander Island, and Charcot Island (Fig. 1).

range in precipitation varies from near zero to over $150 \mathrm{~mm}$ month $^{-1}$. However, we are not able to determine the seasonality or full variability in other components of the freshwater budget west of the WAP, since variability in processes such as iceberg calving, basal melting, etc., is imperfectly resolved. Consequently, we restrict our quantifications here to average monthly rates based on the full length of data available.

The rate of $75 \mathrm{~mm}$ month $^{-1}$ is less than half the freshwater input estimated from the $\delta^{18} \mathrm{O}$ data, a discrepancy due mainly to the absence of consideration of glacial discharge in the RACMO value given above. Inclusion of this contribution is not straightforward: it requires assessment of the proportion of the SMB over land that ultimately relates to glacially derived freshwater input to the ocean west of the Antarctic Peninsula. To include this component in our budget, we first define a "watershed" based on the topography of the Antarctic Peninsula (Fig. 8). The reasonable assumption is made that SMB values to the west of the crests of the mountain ridge correspond to glacial discharge to the ocean at the western coast of the Antarctic Peninsula and that those to the east of the crests relate to input to the western Weddell Sea. \{Note that we use the overall figures for SMB here: while there is a "meltwater runoff" term in the calculation of the RACMO SMB values [Eq. (3)], this is just one component of the overall freshwater budget that will impact on the ocean.\} A simple scaling is used to account for SMB at the ridge crests themselves. Lines of latitude at $63^{\circ}$ and $70^{\circ} \mathrm{S}$ are taken as 


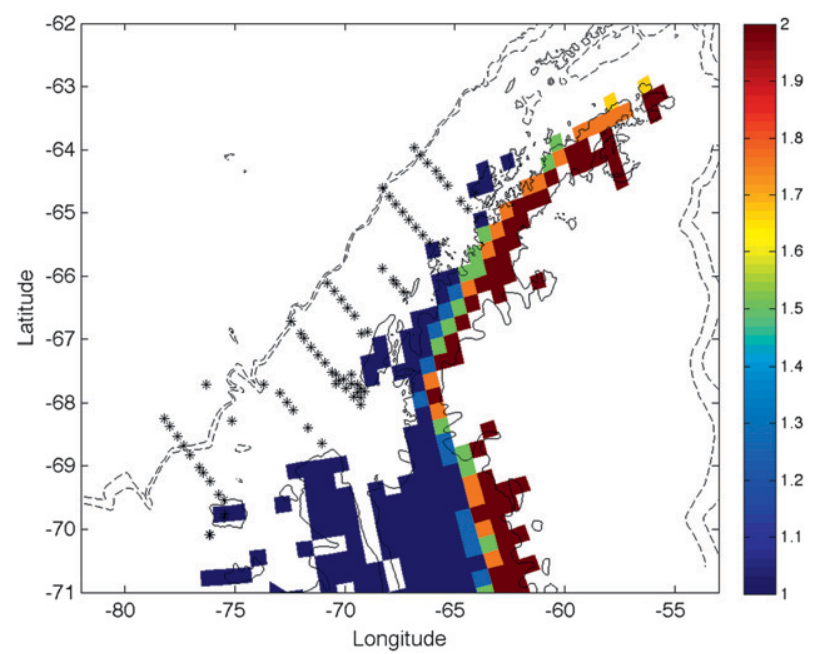

FIG. 8. Mask applied to RACMO SMB fields to determine the freshwater contribution specifically to the ocean west of the Antarctic Peninsula. Dark blue (dark red) grid cells denote those within which SMB is presumed to ultimately influence the ocean to the west (east). Cells marked with intermediate colors are along the crest of the Antarctic Peninsula mountains; RACMO fields in these cells are scaled so as to partially influence the ocean to the west.

limits for SMB that will ultimately influence the region of ocean sampled on the 2011 Pal-LTER cruise.

We note that this calculation could only be completely accurate if the WAP glacial field were in steady state, such that freshwater gain at the surface balanced freshwater loss at the lateral boundaries. While this is not the case, the time scales of Antarctic Peninsula deglaciation are such that it introduces only small errors to the calculation here.

Derived this way, a value of $55 \mathrm{~mm}$ month $^{-1}$ is derived for the glacial discharge to the west, averaged across the area of the Pal-LTER box sampled in 2011. When combined with the RACMO values for precipitation that enters the 2011 Pal-LTER box, the total meteoric water input is around $130 \mathrm{~mm}$ month $^{-1}$ or close to $0.4 \mathrm{~m}$ over the 3 -month period in question. The agreement with the $\delta^{18} \mathrm{O}$-derived value of around $0.5 \mathrm{~m}$ is encouraging, given that the calculation involves a number of implicit assumptions. These include seasonality in glacial discharge being small compared with its mean, accumulation of precipitation on sea ice and its advection leading to no unaccounted loss of meteoric water, and oceanic advection having a net zero effect (i.e., horizontal freshwater loss at the edges of the box being balanced by horizontal freshwater gain). Clearly the latter of these cannot be a completely reliable assumption; however, residence time calculations yield values that are long compared with the input period considered here (see below). Combined, these assumptions
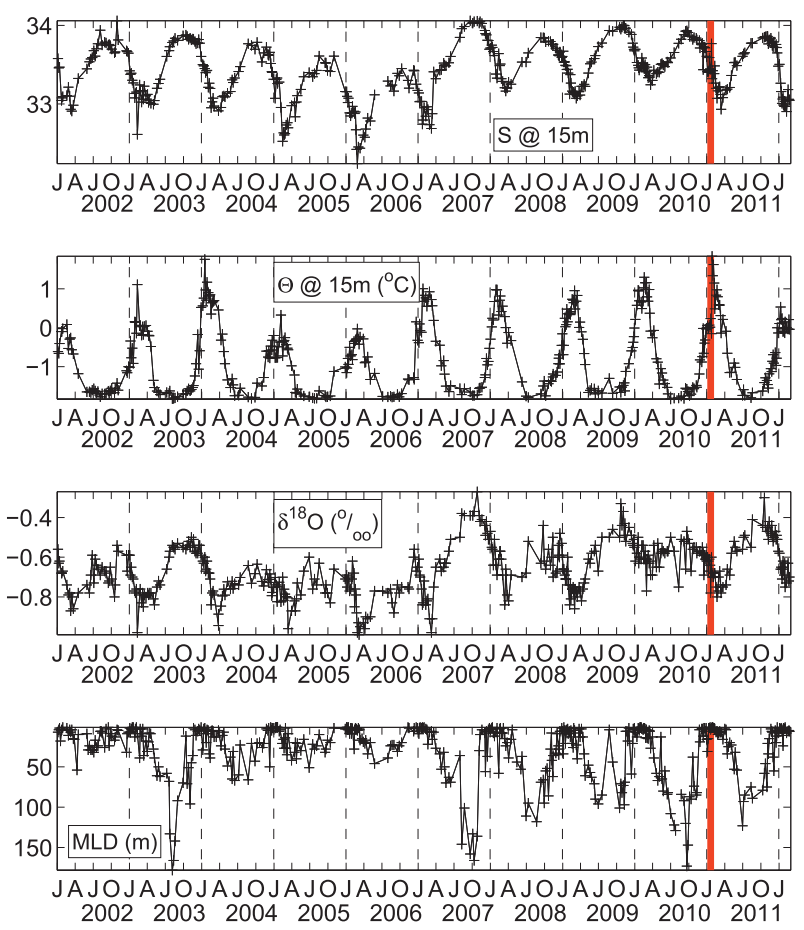

FIG. 9. Time series of (top to bottom) salinity, potential temperature, $\delta^{18} \mathrm{O}$, and mixed layer depth from the RaTS site in northern Marguerite Bay, immediately adjacent to Adelaide Island (Fig. 1). The timing of the 2011 Palmer LTER cruise, from which data are used herein, is shown by the vertical red bar.

will account for at least some of the remaining difference between the RACMO and $\delta^{18} \mathrm{O}$-derived values for total meteoric water input.

A further calculation enabled by the spatial $\delta^{18} \mathrm{O}$ data presented here relates to the residence times of meteoric water on the WAP shelf. For this, we use the total meteoric water prevalences obtained from Eq. (1) and shown in Fig. 2c and integrate them vertically down to a level that is sufficiently deep that the whole meteoric water volume is captured (300 $\mathrm{m}$ in this instance). So doing, a mean value of $\sim 5 \mathrm{~m}$ of meteoric water is obtained from the Pal-LTER profiles, with a standard error of approximately $0.4 \mathrm{~m}$. From RACMO, annual rates of meteoric water input to the 2011 Pal-LTER box are $\sim 1570 \mathrm{~mm}$. Combining these figures, the average residence time for meteoric water in the 2011 Pal-LTER box is estimated to be $\sim 3 \mathrm{yr}$.

\section{c. Temporal context of spatial survey}

Being located approximately midway along the Pal-LTER sampling grid, the RaTS $\delta^{18} \mathrm{O}$ time series from northern Marguerite Bay offers the potential to examine the timing of the 2011 Pal-LTER cruise in the context of temporal variability in the freshwater inputs. The relevant RaTS time series are shown Fig. 9, and it is 

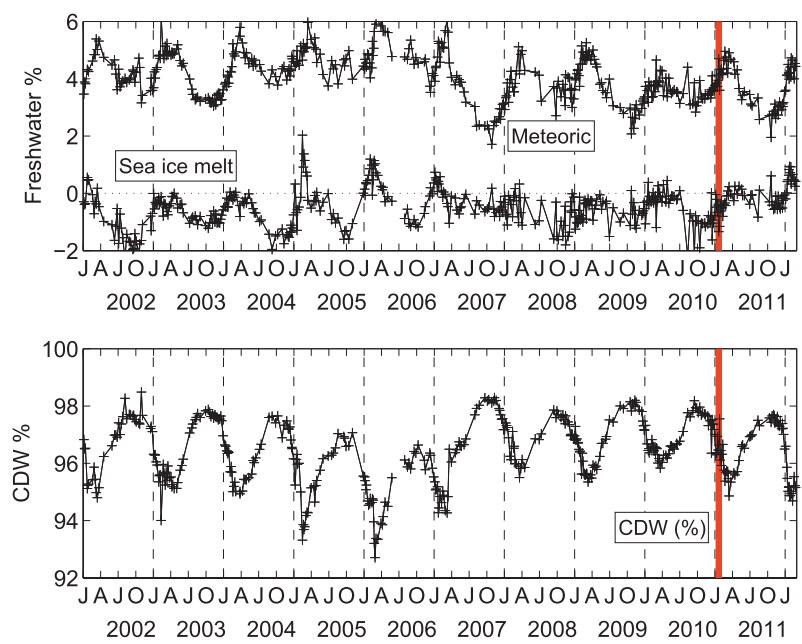

FIG. 10. As in Fig. 9, but for meteoric water and sea ice melt percentages, calculated according to the mass balance shown in Eq. (1). Note the declining prevalence of meteoric water over the duration of the measurements, even in summer.

apparent that the Pal-LTER cruise was conducted at a time when salinity, $\delta^{18} \mathrm{O}$, and mixed layer depth (MLD) were at or approaching their seasonal minima and temperature was close to its seasonal maximum. (MLD is here derived as the depth at which density exceeds the surface density by $0.05 \mathrm{~kg} \mathrm{~m}^{-3}$.) As expected, meteoric water in January 2011 also appears close to its usual seasonal maximum (Fig. 10), though the small seasonality in sea ice melt in recent years makes this contribution harder to assess.

Of particular interest in Fig. 10 are the decadal-scale changes in the freshwater components at RaTS, which show a decline in meteoric water concentration at $15-\mathrm{m}$ depth over the course of the series. Although initially counterintuitive, given the strong deglaciation occurring at the Antarctic Peninsula and the upward trend in precipitation, this is explained by the more frequent occurrence of deep WMLs in recent years (2007 and onward; Fig. 9), which act to distribute the meteoric water received by the ocean over a greater vertical extent and hence diminish its concentration at a fixed depth near the surface.

\section{Discussion and conclusions}

We have presented new quantitative information on the freshwater system at the WAP, using isotope data from a survey that was well placed to capture most of the major inputs. The strong concentrations of meteoric water close to the coast reflect the combined effects of orographic processes on precipitation, and glacial discharge. Meteoric water decreases westward from the coast, creating strong horizontal gradients in salinity. Since this is the controlling variable in the equation of state at low temperature, there are associated gradients in surface density. When considered relative to a level below the ocean mixed layer (i.e., below the direct impact of the freshwater), this creates southward geostrophic current anomalies that can be very significant: typically around $5-10 \mathrm{~cm} \mathrm{~s}^{-1}$, but with a maximum in excess of $30 \mathrm{~cm} \mathrm{~s}^{-1}$. Sea ice melt can also impact on such geostrophic flows, but mostly this is only a second-order contributor.

The strongest geostrophic flow anomalies appear to be located adjacent to the larger islands of the WAP, most notably Adelaide Island and Alexander Island where derived geostrophic velocities are 34 and $20 \mathrm{~cm} \mathrm{~s}^{-1}$, respectively, compared with approximately $5-10 \mathrm{~cm} \mathrm{~s}^{-1}$ on other lines. This is likely a consequence of the more regular coastal topography at these locations being able to better support the structure of the boundary current flows, whereas complex groups of smaller islands and shoals could lead to their breakup. This appears consistent with the descriptions of the APCC and its potential forcing mechanisms, as advanced by Moffat et al. (2008). One implication is that reliable modeling of the physical circulation of the WAP requires accurate representations of precipitation and glacial discharge; otherwise, the derived ocean advection on the inner shelf will be unrealistic and potential advective impacts on the regional ecosystem would be possibly erroneous.

The highest meteoric water values across the survey grid were found at Anvers Island, Adelaide Island, Alexander Island, and Charcot Island. The first three of these are very close to regions identified as having high SMB over land in RACMO, with the implication that glacial discharge here is likely to be strong also. Conversely, Charcot Island is not adjacent to a region notable for high SMB in RACMO. It is, however, very close to the location of the Wilkins Ice Shelf, which has experienced a sequence of large calving events in recent years, most notably in 2008 and 2009 (e.g., Padman et al. 2012). The fate of the freshwater released in these events is not well known; however, it is possible that it has contributed to the elevated meteoric water prevalence measured close to Charcot Island in January 2011. The mean residence time for meteoric water on the WAP shelf has been determined here to be on the order of $3 \mathrm{yr}$ and, while this figure relates to the broader WAP shelf rather than the specific locality of the Wilkins Ice Shelf, it does suggest that there may be some influence that persists over the course of a small number of years.

A further (and perhaps more likely) explanation for the elevated meteoric water concentration found near Charcot Island is its location at the southern end of the 
survey grid, in the path of the southward-flowing waters that lie nearshore farther north (Fig. 1). Freshwater inputs from coastal precipitation and glacial discharge will accumulate in this flow as it advects southward along the WAP, leading to high concentrations of meteoric freshwater in the south.

The distribution of sea ice melt across the survey grid was seen to be patchier than that of meteoric water, reflecting the mobile nature of the sea ice itself. The overall prevalences of sea ice melt are significantly lower than those of meteoric water, indicating that the assertions made previously on the basis of nearshore data that meteoric water is the dominant freshwater source for the WAP ocean are applicable across the whole WAP shelf (Meredith et al. 2008, 2010).

Despite the patchier nature of the sea ice melt distribution, some spatial structure is nonetheless evident, in particular a tendency for net sea ice formation to have occurred from waters sampled in the north of the survey grid and a tendency for net sea ice melt in the south. Combined, this is indicative of a net southward motion in sea ice prior to sampling in January 2011. Satellitederived sea ice motion has indicated general weak northward flow of sea ice in this region (e.g., Emery et al. 1997); however, the strengthening of the northerly winds has led to a reversal of this in recent years, with general southward advection of sea ice now apparent in satellite-derived data (Holland and Kwok 2012).

Using $\delta^{18} \mathrm{O}$ data, we obtain a net input of meteoric water into the area of the Pal-LTER survey grid of around $0.5 \mathrm{~m}$ for the 3 months preceding the January 2011 cruise. This compares with a value of around $0.4 \mathrm{~m}$ for the same quantity derived from RACMO fields, accounting for direct precipitation and glacial discharge. The agreement is encouraging given the numerous assumptions implicit in the calculation, each of which could be significant. Nonetheless it is demonstrated that spatial surveys of $\delta^{18} \mathrm{O}$ in seawater have the potential to add useful quantitative information to assessments of regional freshwater budgets in the coastal Antarctic, especially areas strongly impacted by glacial discharge.

Oxygen isotope data cannot reveal directly which component of meteoric water (precipitation or glacial discharge) dominates the input at the WAP. From RACMO SMB fields, it appears that precipitation is the larger term when averaged over the full area of the Pal-LTER survey grid. A key factor, however, is that, while direct precipitation is distributed (albeit unevenly) over the spatial extent of the ocean, the entire glacial discharge signal enters the WAP ocean at the coast and is thus concentrated strongly in the eastern boundary of the Pal-LTER sampling grid. The impact of this difference can be illustrated by considering a strip of ocean $\sim 25 \mathrm{~km}$ wide at the WAP coast. If glacial discharge were mixed rapidly across this width after entering the ocean, it would be equivalent to more than $400 \mathrm{~mm}$ month $^{-1}$ of freshwater input, compared with around $120 \mathrm{~mm} \mathrm{month}{ }^{-1}$ of freshwater from precipitation into the same strip. This demonstrates that glacial ice discharge is the dominant freshwater source in the coastal and nearshore regions of the WAP, such as where RaTS is situated.

Once in the WAP ocean, the meteoric water resides there for a period estimated here to be $\sim 3 \mathrm{yr}$. Knowledge of this residence time is important, since it is essentially the length of a running-mean filter that the ocean applies to the freshwater inputs. In essence, the impact of year-to-year changes in meteoric water input will be smoothed by mixing with the freshwater already present in the ocean. Formally, the residence time determines for how long measurements must be maintained and how frequently they should be conducted so as to be considered statistically independent, with implications for the derivation of robust trends. The residence time also has potential implications that relate to controls on primary production on the WAP shelf: if glacial discharge is a significant source of trace metal input to the surface WAP ocean, it represents a time scale for the renewal of micronutrient supplies.

It is interesting to note that the residence time of $\sim 3 \mathrm{yr}$ for meteoric water on the WAP shelf appears rather long compared with the advective velocities of up to $30 \mathrm{~cm} \mathrm{~s}^{-1}$ (though more typically $5-10 \mathrm{~cm} \mathrm{~s}^{-1}$ ) that have been derived. Given such strong flows, one might expect the freshwater to be flushed from the system more rapidly (less than $1 \mathrm{yr}$ ). However, it should be recognized that the residence time applies to freshwater across the full width of the WAP shelf, including recirculations on the middle and outer parts, while the high velocities refer to the near-coast boundary current regions and are hence not representative of the true spreading rate of a tracer across the shelf as a whole.

In terms of how representative the $\delta^{18} \mathrm{O}$ survey in January 2011 is of the longer-term freshwater system at the WAP, useful information can be obtained from the near-decade-long series of measurements at the RaTS site in northern Marguerite Bay. While this is in a semienclosed embayment, the representativeness of the $\delta^{18} \mathrm{O}$-derived freshwater components at RaTS over the broader scale of Marguerite Bay and the adjacent WAP shelf was established previously by Meredith et al. (2010). Intriguingly, despite the known deglaciation occurring at the Antarctic Peninsula and the increasing precipitation, the RaTS 15-m isotope data indicate a shift toward lower (not higher) meteoric water concentrations in the near-surface ocean at this site, with the largest change occurring around 2007. While initially 
counterintuitive, these decreasing concentrations are explained by the more frequent occurrence of deep WMLs in recent years, which act to distribute the meteoric water present over a greater vertical extent and hence diminish its concentration at a fixed depth near the surface. In particular, all WMLs have been deep subsequent to 2007 , with only one prior to this. Critically, this is a unidirectional process: once the meteoric water is mixed deep in winter, it does not subsequently reenter the upper ocean, leading to a decline in meteoric water values even in summer (Fig. 10).

The cause of the deeper mixed layers in recent years is a climatic increase in the strength and persistence of northerly winds in winter (Meredith et al. 2010; Venables et al. 2013). This acts to export sea ice southward away from the RaTS site, hence enabling the production of more sea ice in winter, removing buoyancy from the ocean, and promoting deeper mixed layers. The more exposed ocean in winter is also more susceptible to windinduced mixing (e.g., Wallace et al. 2008). Because we understand the drivers for this change and because these drivers are known to have trends over several decades (not just the period of RaTS data coverage), we can assert that this is compelling evidence of a long-term shift toward deep WMLs and reduced meteoric water concentrations in the upper ocean.

Being in a bay that is closed to the north, the RaTS site is potentially more responsive to the increase in northerly winds than other sites farther offshore (e.g., Meredith et al. 2004). Nonetheless, there are likely to be numerous other coastal and near-coastal sites along the WAP that are similarly influenced, and we have seen that these are the locations where meteoric water inputs and concentrations are among the greatest. It is likely also that the increases in northerly winds will also influence the more open shelf regions to a significant extent, by advecting sea ice southward and keeping the ocean open for progressively longer periods each year (Stammerjohn et al. 2008a). An implication of this is that, in regions of the Pal-LTER survey grid where such processes occur, surface meteoric water concentrations prior to 2011 would not necessarily be lower than those measured, despite the deglaciation and precipitation increases known to be occurring at the Antarctic Peninsula. Indeed, they may have been higher.

A further implication of this observed decrease in meteoric water concentrations at the surface in northern Marguerite Bay relates to the input of micronutrients such as iron. As noted above, in the nearshore regions of the WAP, glacial discharge dominates the freshwater budget and could act as a source of such trace metals. However, if the glacial discharge signal is becoming progressively distributed over a greater vertical depth range close to the sites of its injection and is consequently becoming weaker near the surface, this could lead to micronutrient concentrations in the euphotic zone decreasing rather than increasing. As glacially derived freshwaters advect and spread laterally across the shelf and adjacent open ocean, this could have implications for the area of ocean that is not subject to iron limitation of phytoplankton blooms. It is especially relevant in this context that the tendency toward lower meteoric concentrations near the surface is not limited solely to winter, when the deep mixing actually happens, but impacts also on the spring and summer months when primary production occurs.

In the long-term context, it should be noted that each of the freshwater inputs to the WAP is changing. Precipitation is increasing and becoming more liquid, glacial retreat is accelerating, the sea ice season is shortening, and sea ice advection is changing. Each of these changes will impact on the processes observed here, with implications for WAP climate and the regional ecosystem. For example, greater glacial discharge at the coast could potentially accelerate the southward flow associated with the APCC and increase its seasonality, with consequences for the advection of nutrients and plankton in the inner-shelf region of the WAP. However, if the glacially derived freshwater were to be mixed vertically over progressively larger depth ranges, the vertical structure of the velocity change would become more complex and the impacts harder to predict. It is important to increase our understanding of such processes and to include them in regional ecosystem models, if predictive skill is to be developed.

Freshwater inputs to the WAP ocean vary greatly over time and space. The $\delta^{18} \mathrm{O}$ acts as a natural integrator of such varying inputs, while simultaneously quantifying the sea ice inputs separately from meteoric inputs. As such, it has great utility as a component of a freshwater monitoring system. The understanding of the WAP freshwater balance and its impact on the ocean that we obtain from the January $2011 \delta^{18} \mathrm{O}$ survey is the most spatially complete to date, but increased knowledge of the time dependency of the system is required. Future large-scale surveys will be undertaken, alongside continued time series monitoring such as RaTS, to better elucidate the spatial changes in each of the freshwater components and their impacts on regional climate and the ecosystem.

Acknowledgments. We thank the Rothera Marine Assistants for oxygen isotope sampling at RaTS, Carol Arrowsmith for the isotope analyses at NIGL, and Marie Séguret for assistance with data display. We thank Rob Mulvaney and Liz Thomas for advice on isotopes 
in ice cores. The Palmer LTER participants acknowledge Award 0823101 from the Organisms and Ecosystems program in NSF OPP, the officers and crew of $A R S V$ L. M. Gould, and science technicians from Raytheon Polar Services for skilled support of sampling operations. This work is a contribution of the BAS Polar Oceans program, funded by the Natural Environment Research Council.

\section{REFERENCES}

Abram, N. J., R. Mulvaney, and C. Arrowsmith, 2011: Environmental signals in a highly resolved ice core from James Ross Island, Antarctica. J. Geophys. Res., 116, D20116, doi:10.1029/ 2011JD016147.

Annett, A. L., S. F. Henley, P. van Beck, M. Souhaut, R. Ganeshram, H. J. Venables, M. P. Meredith, and W. Geibert, 2013: Use of radium isotopes to estimate mixing rates and trace sediment inputs to surface waters in northern Marguerite Bay (Antarctic Peninsula). Antarct. Sci., doi:10.1017/S0954102012000892, in press.

Boyd, P. W., and M. J. Ellwood, 2010: The biogeochemical cycle of iron in the ocean. Nat. Geosci., 3, 675-682.

Cook, A. J., A. J. Fox, D. G. Vaughan, and J. G. Ferrigno, 2005: Retreating glacier fronts on the Antarctic Peninsula over the past half-century. Science, 308, 541-544.

Craig, H., and L. Gordon, 1965. Deuterium and oxygen-18 variations in the ocean and the marine atmosphere. Stable Isotopes in Oceanographic Studies and Paleotemperatures, E. Tongiorgio, Ed., Spoleto, 9-130.

Dierssen, H. M., R. C. Smith, and M. Vernet, 2002: Glacial meltwater dynamics in coastal waters west of the Antarctic Peninsula. Proc. Natl. Acad. Sci. USA, 99, 1790-1795.

Ducklow, H. W., and Coauthors, 2012: The marine system of the western Antarctic Penninsula. Antarctic Ecosystems: An Extreme Environment in a Changing World, A. D. Rogers et al., Eds., John Wiley \& Sons, 121-159.

Edwards, R., and P. Sedwick, 2001: Iron in East Antarctic snow: Implications for atmospheric iron deposition and algal production in Antarctic waters. Geophys. Res. Lett., 28, 39073910.

Emery, W. J., C. W. Fowler, and J. A. Maslanik, 1997: Satellitederived maps of Arctic and Antarctic ice motion: 1988 to 1994. Geophys. Res. Lett., 24, 897-900.

Epstein, S., and T. K. Mayeda, 1953: Variation of 180 content of waters from natural sources. Geochim. Cosmochim. Acta, 4, 213-224.

Gille, S., 2008: Decadal-scale temperature trends in the Southern Hemisphere ocean. J. Climate, 21, 4749-4765.

Hofmann, E. E., J. M. Klinck, C. M. Lascara, and D. A. Smith, 1996: Water mass distribution and circulation west of the Antarctic Peninsula and including Bransfield Strait. Foundations for Ecological Research West of the Antarctic Peninsula, R. M. Ross, E. E. Hofmann, and L. B. Quetin, Eds., Antarctic Research Series, Vol. 70, Amer. Geophys. Union, 61-80.

Holland, P. R., and R. Kwok, 2012: Wind-driven trends in Antarctic sea-ice drift. Nat. Geosci., 5, 872-875, doi:10.1038/ ngeo1627.

Ivins, E. R., M. M. Watkins, D.-N. Yuan, R. Dietrich, G. Casassa, and A. Rülke, 2011: On-land ice loss and glacial isostatic adjustment at the Drake Passage: 2003-2009. J. Geophys. Res., 116, B02403, doi:10.1029/2010JB007607.

King, J. C., 1994: Recent climate variability in the vicinity of the Antarctic Peninsula. Int. J. Climatol., 14, 357-369.

, and S. A. Harangozo, 1998: Climate change in the western Antarctic Peninsula since 1945: Observations and possible causes. Ann. Glaciol., 27, 571-575.

Kirchgäßner, A., 2011: An analysis of precipitation data from the Antarctic base Faraday/Vernadsky. Int. J. Climatol., 31, 404414.

Klinck, J. M., 1998: Heat and salt changes on the continental shelf west of the Antarctic Peninsula between January 1993 and January 1994. J. Geophys. Res., 103 (C4), 7617-7636.

Lehmann, M., and U. Siegenthaler, 1991: Equilibrium oxygenand hydrogen-isotope fractionation between ice and water. J. Glaciol., 57, 23-26.

Lenaerts, J. T. M., M. R. van den Broeke, W. J. van den Berg, E. van Meijgaard, and P. K. Munneke, 2012: A new, highresolution surface mass balance map of Antarctica (1979-2010) based on regional atmospheric climate modeling. Geophys. Res. Lett., 39, L04501, doi:10.1029/2011GL050713.

Marshall, G. J., A. Orr, N. van Lipzig, and J. King, 2006: The impact of a changing Southern Hemisphere annular mode on Antarctic Peninsula summer temperatures. J. Climate, 19, 5388-5404.

Martinson, D. G., 2011a: Antarctic Circumpolar Current's role in the Antarctic ice system: An overview. Palaeogeogr. Palaeoclimatol. Palaeoecol., 335-336, 71-74.

,2011b: Transport of warm Upper Circumpolar Deep Water onto the western Antarctic Peninsula continental shelf. Ocean Sci., 8, 433-442.

, S. E. Stammerjohn, R. A. Iannuzzi, R. C. Smith, and M. Vernet, 2008: Western Antarctic Peninsula physical oceanography and spatio-temporal variability. Deep-Sea Res. II, 55, 1964-1987.

Meredith, M. P., and J. C. King, 2005: Rapid climate change in the ocean to the west of the Antarctic Penisula during the second half of the 20th century. Geophys. Res. Lett., 32, L19604, doi:10.1029/2005GL024042.

— I. A. Renfrew, A. Clarke, J. C. King, and M. A. Brandon, 2004: Impact of the 1997/98 ENSO on upper ocean characteristics in Marguerite Bay, western Antarctic Peninsula. J. Geophys. Res., 109, C09013, doi:10.1029/2003JC001784.

—, M. A. Brandon, M. I. Wallace, A. Clarke, M. J. Leng, I. A. Renfrew, N. P. M. van Lipzig, and J. C. King, 2008. Variability in the freshwater balance of northern Marguerite Bay, Antarctic Peninsula: Results from $\delta^{18}$ O. Deep-Sea Res. II, 55, 309322.

- and Coauthors, 2010: Changes in the freshwater composition of the upper ocean west of the Antarctic Peninsula during the first decade of the 21st century. Prog. Oceanogr., 87, 127-143.

Mitchell, B. G., and O. Holm-Hansen, 1991: Observations and modeling of the Antarctic phytoplankton crop in relation to mixing depth. Deep-Sea Res., 38, 981-1007.

Moffat, C., R. Beardsley, W. B. Owens, and N. van Lipzig, 2008: A first description of the Antarctic Peninsula Coastal Current. Deep-Sea Res. II, 55, 277-293.

— B. Owens, and R. C. Beardsley, 2009: On the characteristics of Circumpolar Deep Water intrusions to the west Antarctic Peninsula continental shelf. J. Geophys. Res., 114, C05017, doi:10.1029/2008JC004955.

Montes-Hugo, M., S. C. Doney, H. W. Ducklow, W. Fraser, D. Martinson, S. E. Stammerjohn, and O. Schofield, 2009: Recent changes in phytoplankton communities associated 
with rapid regional climate change along the western Antarctic Peninsula. Science, 323, 1470-1473.

Morgan, V. I., 1982: Antarctic ice sheet surface oxygen isotope values. J. Glaciol., 28, 315-323.

Mulvaney, R., E. C. Pasteur, D. A. Peel, S. Saltzman, and P. Whung, 1992: The ratio of MSA to non-sea-salt sulphate in Antarctic Peninsula ice cores. Tellus, 44B, 295-303.

Nicolas, J. P., and D. H. Bromwich, 2011: Precipitation changes in high southern latitudes from global reanalyses: A cautionary tale. Surv. Geophys., 32, 475-494.

Ostlund, H. G., and G. Hut, 1984: Arctic Ocean water mass balance from isotope data. J. Geophys. Res., 89 (C10), 6373-6381.

Padman, L., and Coauthors, 2012: Oceanic controls on the mass balance of Wilkins Ice Shelf, Antarctica. J. Geophys. Res., 117, C01010, doi:10.1029/2011JC007301.

Potter, J. R., and J. G. Paren, 1985: Interaction between ice shelf and ocean in George VI Sound, Antarctica. Oceanology of the Antarctic Continental Shelf, S. Jacobs, Ed., Antarctic Research Series, Vol. 43, Amer. Geophys. Union, 35-58.

Pritchard, H. D., S. R. M. Ligtenberg, H. A. Fricker, D. G. Vaughan, M. R. van den Broeke, and L. Padman, 2012: Antarctic ice-sheet loss driven by basal melting of ice shelves. Nature, 484, 502-505.

Raiswell, R., 2011: Iceberg-hosted nanoparticulate $\mathrm{Fe}$ in the Southern Ocean mineralogy, origin, dissolution kinetics and source of bioavailable Fe. Deep-Sea Res. II, 58, 1364-1375.

Scambos, T., H. A. Fricker, C. C. Liu, J. Bohlander, J. Fastook, A. Sargent, R. Massom, and A. M. Wu, 2009: Ice shelf disintegration by plate bending and hydro-fracture: Satellite observations and model results of the 2008 Wilkins ice shelf break-ups. Earth Planet. Sci. Lett., 280, 51-60.

Schlosser, P., R. Bayer, A. Foldvik, T. Gammelsrod, G. Rohardt, and K. O. Munnich, 1990: Oxygen 18 and helium as tracers of ice shelf water and water/ice interaction in the Weddell Sea. J. Geophys. Res., 95 (C3), 3253-3263.

Smith, R. C., and S. E. Stammerjohn, 2001: Variations of surface air temperature and sea ice extent in the western Antarctic Peninsula (WAP) region. Ann. Glaciol., 33, 493-500.

$\longrightarrow,-$, and K. S. Baker, 1996: Surface air temperature variations in the western Antarctic Peninsula regions. Foundations for Ecological Research West of the Antarctic Peninsula, R. M. Ross, E. E. Hofmann, and L. B. Quetin, Eds., Antarctic Research Series, Vol. 70, Amer. Geophys. Union, 105-121.

Stammerjohn, S. E., D. G. Martinson, R. C. Smith, and R. A. Ianuzzi, 2008a: Sea ice in the western Antarctic Peninsula region: Spatio-temporal variability from ecological and climate change perspectives. Deep-Sea Res. II, 55, 20412058.

,,,--- X. Yuan, and D. Rind, 2008b: Trends in Antarctic annual sea ice retreat and advance and their relation to El
Niño-Southern Oscillation and southern annular mode variability. J. Geophys. Res., 113, C03S90, doi:10.1029/2007JC004269.

Thoma, M., A. Jenkins, D. Holland, and S. Jacobs, 2008: Modelling Circumpolar Deep Water intrusions on the Amundsen Sea continental shelf, Antarctica. Geophys. Res. Lett., 35, L18602, doi:10.1029/2008GL034939.

Thomas, E. R., G. J. Marshall, and J. R. McConnell, 2008: A doubling in snow accumulation in the western Antarctic Peninsula. Geophys. Res. Lett., 35, L01706, doi:10.1029/ 2007GL032529.

_ , P. F. Dennis, T. J. Bracegirdle, and C. Franzke, 2009: Ice core evidence for significant 100-year regional warming on the Antarctic Peninsula. Geophys. Res. Lett., 36, L20704, doi:10.1029/ 2009GL040104

Thompson, L. G., D. A. Peel, E. Mosley-Thompson, R. Mulvaney, J. Dai, P. N. Lin, M. E. Davis, and C. F. Raymond, 1994: Climate since AD1510 on Dyer Plateau, Antarctic Peninsula: Evidence for recent climate change. Ann. Glaciol., 20, 420426.

Tomczak, M., and D. G. B. Large, 1989: Optimum multiparameter analysis of mixing in the thermocline of the eastern Indian Ocean. J. Geophys. Res., 94 (C11), 16 141-16 149.

Turner, J., S. R. Colwell, and S. Harangozo, 1997: Variability of precipitation over the coastal western Antarctic Peninsula from synoptic observations. J. Geophys. Res., 102 (C12), 13 999-14 007.

, and Coauthors, 2005: Antarctic climate change during the last 50 years. Int. J. Climatol., 25, 279-294.

_ change induced by stratospheric ozone depletion and its role in the recent increase in Antarctic sea ice extent. Geophys. Res. Lett., 36, L08502, doi:10.1029/2009GL037524.

_ - E. Maksym, A. Phillips, G. J. Marshall, and M. P. Meredith, 2013: The impact of changes in sea ice advance on the large winter warming on the western Antarctic Peninsula. Int. J. Climatol., doi:10.1002/joc.3474, in press.

Vaughan, D. G., 2006: Recent trends in melting conditions on the Antarctic Peninsula and their implications for ice-sheet mass balance and sea level. Arct. Antarct. Alp. Res., 38, 147-152.

__ and Coauthors, 2003: Recent rapid regional climate warming on the Antarctic Peninsula. Climatic Change, 60, 243-274.

Venables, H. J., A. Clarke, and M. P. Meredith, 2013: Wintertime controls on summer stratification and productivity at the western Antarctic Peninsula. Limnol. Oceanogr., in press.

Wallace, M. I., M. P. Meredith, M. A. Brandon, T. J. Sherwin, A. Dale, and A. Clarke, 2008: On the characteristics of internal tides and coastal upwelling behaviour in Marguerite Bay, west Antarctic Peninsula. Deep-Sea Res. II, 55, 2023-2040.

Weiss, R. F., H. G. Ostlund, and H. Craig, 1979: Geochemical studies of the Weddell Sea. Deep-Sea Res., 26A, 1093-1120. 